\title{
ANALISIS PERENCANAAN STRATEGI SISTEM DAN TEKNOLOGI INFORMASI PADA SMK YAMATU TUALANG
}

Syaifullah

Universitas Islam Negeri Syarif Kasim Riau syaifullah@uin-suska.ac.id Megawati

Universitas Islam Negeri Syarif Kasim Riau megawati@uin-suska.ac.id
Nora Ferwati

Universitas Islam Negeri Syarif Kasim Riau nora.ferwati@student.uin-suska.ac.id Tengku Khairil Ahsyar

Universitas Islam Negeri Syarif Kasim Riau tengkukhairil@uin-suska.ac.id

\begin{abstract}
ABSTRAK
SMK Yamatu Tualang merupakan sekolah yang termasuk dalam kelompok sekolah bisnis dan manajemen serta teknologi dan rekayasa. Dalam menjalankan proses sebagai organisasi yang bergerak dibidang pendidikan SMK Yamatu Tualang memiliki beberapa permasalahan baik dari kondisi internal maupun kondisi eksternal diantaranya $80 \%$ sekolah tidak meyediakan sarana untuk penerapan TI dan komunikasi serta sekolah mengalami ketertinggalan dari beberapa sekolah pesaing dalam penerapan SI/TI. Penelitian ini bertujuan untuk membuat portofolio aplikasi perencanaan strategi sistem dan TI sebagai perencanaan kedepan pada SMK Yamatu Tualang. Perencanaan strategi sistem dan TI ini menggunakan metode Ward and Peppard dan tools yang akan digunakan untuk analisa antara lain menggunakan analisis SWOT, CSF, Porter Five Forces dan Mc Farlan Strategic Grid. Dari hasil analisis dapat dirumuskan portofolio aplikasi perencanaan strategi sistem dan TI yang dibutuhkan SMK Yamatu Tualang yaitu website resmi sekolah, SI akademik, SI kepegawaian, aplikasi E-kurikulum, SI PPDB online, SI alumni dan karir serta SI perpustakaan.
\end{abstract}

Kata kunci: Perencanaan Strategi SI/TI, SMK Yamatu Tualang, Ward and Peppard.

\section{ABSTRACT}

SMK Yamatu Tualang Vocational School is a school that belongs to the business and management school group as well as technology and engineering. In carrying out the process as an organization engaged in education, Yamatu Tualang Vocational School has several problems both from internal conditions and external conditions including $80 \%$ of schools do not provide facilities for the application of IT and communication and schools experience lags from several competing schools in the application of IS / IT. This study aims to create a portfolio of systems and IT strategy planning applications as a future planning for SMK Yamatu Tualang. This system and IT strategy planning uses the Ward and Peppard method and the tools that will be used for analysis include using SWOT analysis, CSF, Porter Five Forces and Mc Farlan Strategic Grid. From the results of the analysis can be formulated a portfolio of system and IT strategy planning applications needed by Yamatu Tualang Vocational School, namely the official school website, academic SI, employment SI, E-curriculum application, SI PPDB online, SI alumni and career and SI library.

Keywords: IS/IT Strategic Planning, SMK Yamatu Tualang, Ward and Peppard.

\section{Pendahuluan}

Peranan Sistem Informasi (SI) dan Teknologi Informasi (TI) saat ini dalam dunia pendidikan begitu sangat dirasakan, dimana kecepatan penyampaian informasi menjadi sangat penting di dalam memajukan dunia pendidikan. Pemanfaatan dan pendayagunaan SI/TI di sekolah dapat menjadi salah satu upaya di dalam meningkatkan daya saing dan mutu pendidikan di Indonesia. Perencanaan strategi SI merupakan proses identifikasi portofolio aplikasi SI berbasis komputer yang akan mendukung organisasi dalam pelaksanaan rencana bisnis dan merealisasikan tujuan bisnis nya. Perencanaan strategi SI mempelajari pengaruh-pengaruh SI terhadap kinerja bisnis dan kontribusi bagi manajemen untuk menyelaraskan strategi sistem dengan strategi bisnis, bahkan mencari kesempatan baru melalui penerapan teknologi yang inovatif [9].

SMK Yamatu Tualang merupakan salah satu sekolah menengah kejuruan milik swasta yang ada di Perawang Kecamatan Tualang Kabupaten Siak. Di sekolah ini terdapat beberapa jurusan seperti Administrasi Perkantoran, Teknik Instalasi Pemanfaatan Tenaga Listrik, Teknik Otomotif Kendaraan Ringan, Teknik Otomotif Sepeda Motor dan Agribisnis Pembibitan dan Kultur Jaringan. SMK Yamatu Tualang termasuk dalam kelompok sekolah bisnis manajemen dan teknologi serta rekayasa, visi dari SMK Yamatu adalah "Terwujudnya SMK Yamatu Tualang sebagai pusat pendidikan dan pelatihan kejuruan di bidang bisnis dan manajemen serta teknik serta sebagai wadah untuk menciptakan tenaga kerja yang berdisiplin, berkualitas, berakhlak mulia, serta terampil melalui keunggulan kompetitif dengan berbudaya melayu dan mampu bersaing dalam era globalisasi".

Dalam menjalankan proses sebagai suatu organisasi yang bergerak dibidang jasa pendidikan, SMK Yamatu Tualang mempunyai beberapa permasalahan diantaranya:

1. Banyak siswa yang tidak memahami bidang studi yang diminatinya karena tidak adanya kebijakan tes tertulis dan media sosialisasi yang dapat memberi informasi mengenai jurusan yang ada di sekolah seperti website sekolah yang mengakibatkan keterbatasan kemampuan siswa dalam mengimplementasikan pembelajaran praktek di dunia usaha atau di dunia industri. 
2. Banyak guru yang mengajar tidak sesuai dengan bidangnya, hal ini disebabkan karena kurangnya tenaga pendidik yang produktif, tidak semua guru yang mengajar berlatar belakang sarjana pendidikan serta kurangnya buku pengetahuan dan tidak tersedianya $e$-Book di sekolah, serta media pembelajaran seperti e-Learning sehingga mengakibatkan guru mengalami kesulitan dalam memahami bidang studi yang diajarkannya.

3. Banyak siswa yang tidak tertarik untuk mengunjungi perpustakaan sekolah karena belum adanya penjaga atau pengurus perpustakaan yang tetap, koleksi buku pengetahuan yang belum lengkap serta belum menggunakan sistem perpustakaan.

4. Terjadinya persaingan antar sekolah karena adanya pesaing seperti SMK yang memiliki jurusan yang sama dan munculnya SMA yang biayanya gratis sehingga mempengaruhi besar kecilnya jumlah peminat sekolah.

5. Panitia penerimaan siswa baru mengalami kesulitan dalam proses pendaftaran siswa baru sampai proses pengumuman hasil penerimaan siswa baru karena sistem pendaftaran masih menggunakan sistem manual yaitu belum menggunakan sistem informasi pendaftaran yang berbasis teknologi.

6. Sekolah belum memiliki website karena $80 \%$ sekolah tidak menyediakan sarana untuk penerapan TI dan komunikasi seperti website sekolah sehingga dalam kegiatan promosi sekolah hanya menggunakan spanduk dan brosur.

7. Sekolah hanya menyediakan wifi dengan kecepatan akses 3 mbps dan hanya dapat digunakan oleh guru untuk kepentingan pribadi yang menyebabkan kerugian karena investasi TI tidak dimanfaatkan dengan seharusnya.

8. Sekolah mengalami ketertinggalan dari beberapa sekolah pesaing dalam penerapan SI/TI karena sekolah belum optimal dalam menerapkan SI dan TI sebagai sarana penting untuk kinerja sekolah.

Permasalahan yang dialami sekolah tersebut perlu dilakukan pembuatan rencana strategi dari segi SI dan TI nya dikarenakan beberapa alasan yang dikemukakan oleh Ward and Peppard, yaitu investasi pada SI/TI tidak mendukung sasaran bisnis, tidak terkontrolnya SI/TI yang ada dan organisasi tidak memiliki panduan untuk prioritas proyek SI/TI. Untuk menyusun perencanaan strategi sistem dan teknologi informasi langkah pertama yang dilakukan yaitu analisis lingkungan bisnis internal seperti strategi bisnis yang dijalankan saat ini. Kedua lingkungan bisnis eksternal seperti kondisi ekonomi dan persaingan saat ini. Ketiga lingkungan SI/TI internal seperti TI yang dipakai saat ini. Terakhir lingkungan SI/TI eksternal seperti tren teknologi saat ini.

Berdasarkan penjabaran masalah, penyebab hingga akibat yang ditimbulkan dari masalah tersebut, maka dilakukan penelitian mengenai Analisis Perencanaan Strategi Sistem dan Teknologi Informasi pada SMK Yamatu Tualang.

A. Pengertian Perencanaan Strategi

Perencanaan adalah salah satu fungsi manajer yang meliputi seleksi atas alternatif-alternatif tujuan, kebijakan-kebijakan, program dan prosedur [3]. Suatu strategi perusahaan (company's strategy) didefinisikan sebagai "rencana permainan (game plan) yang dilakukan oleh manajemen untuk memposisikan perusahaan di dalam arena pasar yang dipilih supaya dapat memenangkan kompetisi, memuaskan pelanggannya dan mencapai kinerja bisnis yang baik [2]. Strategi sebenarnya adalah suatu bentuk kegiatan, cara, atau pendekatan yang diterapkan manajer-manajer untuk memuaskan pelanggannya, membentuk posisi pasar yang menarik, dan mencapai sasaran-sasaran organisasi [4]. Perencanaan strategi adalah suatu rencana jangka panjang yang bersifat menyeluruh, memberikan rumusan kemana suatu organisasi atau perusahaan akan diarahkan, dan bagaimana sumber daya dialokasikan untuk mencapai tujuan selama jangka waktu tertentu dalam berbagai kemungkinan keadaan lingkungan [1]. Perencanaan strategi yaitu proses memutuskan programprogram yang akan dilaksanakan oleh organisasi dan perkiraan jumlah sumber daya yang akan dialokasikan ke setiap program jangka panjang selama beberapa tahun kedepan [1].

B. Perencanaan Sistem dan Teknologi Informasi

Sistem informasi adalah suatu sistem yang dibuat oleh manusia yang terdiri dari komponenkomponen dalam organisasi untuk mencapai suatu tujuan yaitu menyajikan informasi [8]. Sistem informasi merupakan kumpulan dari perangkat keras dan perangkat lunak komputer serta perangkat manusia yang akan mengolah data menggunakan perangkat keras dan perangkat lunak tersebut [5]. Perencanaan strategi sistem infromasi merupakan proses identifikasi portofolio aplikasi sistem informasi berbasis komputer yang akan mendukung organisasi dalam pelaksanaan rencana bisnis dan merealisasikan tujuan bisnis nya. Perencanaan strategi sistem informasi mempelajari pengaruhpengaruh sistem informasi terhadap kinerja bisnis dan kontribusi bagi manajemen untuk menyelaraskan strategi sistem dengan strategi bisnis, bahkan mencari kesempatan baru melalui penerapan teknologi yang inovatif [9]. 


\section{Metode Penelitian}

Penelitian ini menggunakan metode Ward and Peppard. Pendekatan metodologi versi Ward and Peppard ini dimulai dari kondisi investasi SI/TI dimasa lalu yang kurang bermanfaat bagi tujuan bisnis organisasi dan menangkap peluang bisnis, serta fenomena meningkatkan keunggulan kompetitif suatu organisasi karena mampu memanfaatkan SI/TI dengan maksimal. Kurang bermanfaatnya investasi SI/TI bagi organisasi disebabkan karena perencanaan strategi SI/TI yang lebih fokus ke teknologi, bukan berdasarkan kebutuhan bisnis. Model tersebut ditunjukkan pada Gambar 1.

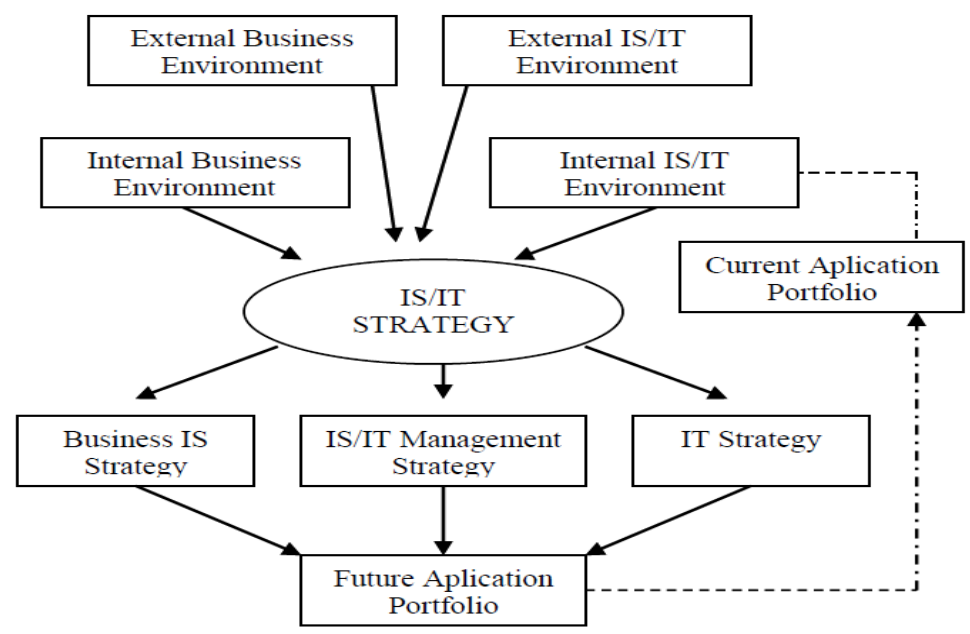

Gambar 1 Model Perencanaan Strategi sistem dan teknologi informasi menurut Ward and Peppard

(Sumber : Ward and Peppard, 2002 dikutip oleh Wedhasmara, 2009)

Gambaran model diatas terdiri dari input dan output. Inputnya yaitu :

1. Analisis lingkungan bisnis internal, yang mencakup aspek-aspek strategi bisnis saat ini, sasaran, sumber daya, proses, serta budaya nilai-nilai bisnis organisasi.

2. Analisis lingkungan bisnis eksternal, yang mencakup aspek-aspek ekonomi, industri, dan iklim bersaing perusahaan.

3. Analisis lingkungan SI/TI internal, yang mencakup kondisi SI/TI organisasi dari perspektif bisnis saat ini, bagaimana kematangannya (maturity), bagaimana kontribusi terhadap bisnis, keterampilan sumber daya manusia, sumber daya dan infrastruktur teknologi, termasuk juga bagaimana portofolio dari SI/TI yang ada saat ini.

4. Analisis lingkungan SI/TI eksternal, yang mencakup tren teknologi dan peluang pemanfaatannya, serta penggunaan SI/TI oleh kompetitor, pelanggan dan pemasok.

Sedangkan tahapan keluaran merupakan bagian yang dilakukan untuk menghasilkan suatu dokumen perencanaan strategi SI/TI yang isinya terdiri dari:

1. Strategi SI bisnis, yang mencakup bagaimana setiap unit/fungsi bisnis akan memanfaatkan SI/TI untuk mencapai sasaran bisnisnya, portofolio aplikasi dan gambaran arsitektur informasi.

2. Strategi TI, yang mencakup kebijakan dan strategi bagi pengelolaan teknologi dan sumber daya manusia SI/TI.

3. Strategi Manajemen SI/TI, yang mencakup elemen-elemen umum yang diterapkan melalui organisasi, untuk memastikan konsistensi penerapan kebijakan SI/TI yang dibutuhkan.

\section{Teknik Analisis}

1. Analisis SWOT

Analisis ini didasarkan pada logika yang dapat memaksimalkan kekuatan (Strengths) dan peluang (opportunities), namun secara bersamaan dapat meminimalkan kelemahan (Weaknesses) dan ancaman (Threats) [7]

2. Analisis Critical Success Factor's (CSF)

Critical success factors (CSF) merupakan sebuah strategi analisis yang membantu seorang manajer untuk mencapai tujuan dari perusahaan, termasuk faktor-faktor yang akan mempengaruhi keberhasilan atau kegagalan pencapaian tujuan [1].

3. Analisis Five Force Porter

Porter menjelaskan bahwa persaingan terdiri dari lima ancaman-ancaman (sekaligus dapat menjadi kesempatan-kesempatan), yaitu ancaman pesaing yang sudah ada, ancaman pesaing baru, ancaman produk pengganti, kekuatan menawar dari pelanggan-pelanggan dan kekuatan menawar dari pemasok-pemasok [2]. 
4. Analisis Mc Farlan Strategic Grid

Model pemetaan Mc Farlan bertujuan untuk menganalisis suatu aplikasi atau SI disuatu kegiatan operasional berdasarkan kondidi saat ini, kondisi yang direncanakan serta aplikasi yang dianggap berpotensi menunjang bisnis operasional [1].

\subsection{Analisis Lingkungan Bisnis Internal Organisasi}

\section{Hasil dan Analisis.}

a. Analisis SWOT

Hasil analisis SWOT yang dilakukan sesuai dengan aspek-aspek kondisi internal sekolah adalah:

Tabel 1 Hasil Analisis SWOT

\begin{tabular}{|c|c|}
\hline Analisis Kekuatan & Analisis Kelemahan \\
\hline $\begin{array}{l}\text { a. Memiliki program keahlian yang } \\
\text { dibutuhkan oleh Dunia Usaha/Dunia } \\
\text { Industri (DU/DI) } \\
\text { b. Gedung sekolah milik sendiri } \\
\text { c. Letak sekolah yang strategis } \\
\text { d. Sekolah memiliki akreditasi A }\end{array}$ & $\begin{array}{l}\text { a. Pendaftaran bagi calon siswa baru masih manual } \\
\text { b. Belum memiliki sistem sendiri untuk menyimpan data siswa } \\
\text { c. Sekolah kekurangan tenaga pendidik produktif } \\
\text { d. Peralatan praktek peserta didik yang masih kurang mencukupi } \\
\text { e. Tidak tersedianya sarana untuk penerapan teknologi informasi dan } \\
\text { komunikasi } \\
\text { f. Ketersediaan bandwidth internet yang terbatas dan belum merata }\end{array}$ \\
\hline Analisis Peluang & Analisis Ancaman \\
\hline $\begin{array}{l}\text { a. Program keahlian memenuhi } \\
\text { kebutuhan DU/DI } \\
\text { b. Adanya hubungan kerja sama dengan } \\
\text { perusahaan ternama } \\
\text { c. Banyak peminat dari lulusan SMP } \\
\text { d. Lokasi sekolah strategis }\end{array}$ & $\begin{array}{l}\text { a. Persaingan dari sekolah lain baik swasta maupun negeri yang } \\
\text { memiliki program keahlian yang sama } \\
\text { b. Munculnya sekolah negeri yang biayanya gratis } \\
\text { c. Permintaan lulusan yang berkualitas tinggi } \\
\text { d. Persaingan antar lulusan dalam merebut peluang kerja sangant tinggi } \\
\text { e. Perkembangan teknologi yang semakin cepat } \\
\text { f. Regulasi dan kebijakan pemerintah yang selalu berubah }\end{array}$ \\
\hline
\end{tabular}

Setelah mengidentifikasi SWOT lalu dibuatlah matriks analisis pada Tabel Matriks SWOT yang mana hasil matriksnya serta hasil identifikasi strateginya dapat dilihat pada tabel dibawah ini:

Tabel 2 Matriks SWOT

\begin{tabular}{|c|c|c|c|}
\hline \multirow{2}{*}{\multicolumn{2}{|c|}{ Eksternal Internal }} & Kekuatan & Kelemahan \\
\hline & & 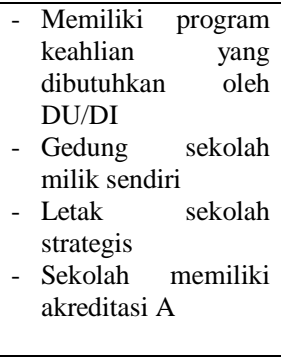 & $\begin{array}{l}\text { - Pendaftaran bagi calon siswa baru masih manual } \\
\text { - Belum memiliki sistem sendiri untuk } \\
\text { menyimpan data siswa } \\
\text { - Tidak adanya test dalam pemilihan jurusan } \\
\text { - Sekolah kekurangan tenaga pendidik produktif } \\
\text { - Peralatan praktek peserta didik yang masih } \\
\text { kurang mencakupo } \\
\text { - Tidak tersedianya sarana untuk penerapan } \\
\text { teknologi informasi dan komunikasi } \\
\text { - Ketersediaan bandwidth internet yang terbatas } \\
\text { dan belum merata }\end{array}$ \\
\hline 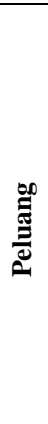 & $\begin{array}{l}\text { - Program Keahlian memenuhi } \\
\text { kebutuhan DU/DI } \\
\text { - Adanya hubungan kerja sama } \\
\text { dengan perusahaan ternama } \\
\text { - Banyak peminat dari lulusan } \\
\text { SMP } \\
\text { - Lokasi Strategis } \\
\text { - Memiliki sertifikat Akreditasi } \\
\text { A }\end{array}$ & $\begin{array}{l}\text { Strategi Pemanfaatan } \\
\text { Kekuatan dan } \\
\text { Peluang } \\
\text { - Melakukan promosi } \\
\text { melalui media online } \\
\text { agar dapat diakses } \\
\text { oleh masyarakat luas } \\
\text { - Menyalurkan siswa } \\
\text { PKL dan lulusan ke } \\
\text { perusahaan DU/DI }\end{array}$ & $\begin{array}{l}\text { Strategi Mengatasi Kelemahan } \\
\text { Pemanfaatan Peluang } \\
\text { - Meningkatkan sarana dan prasarana untuk } \\
\text { meningkatkan kegiatan belajar mengajar } \\
\text { - Melaksanakan kegiatan sosialisasi dan } \\
\text { komunikasi mengenai program keahlian } \\
\text { - Melakukan pelatihan teknologi untuk semua } \\
\text { SDM } \\
\text { - Perlu dibuatkan media berbasis web sebagai } \\
\text { media promosi } \\
\text { - Perlu adanya sistem informasi akademik dalam } \\
\text { pengaturan kegiatan sekolah seperti pendaftaran } \\
\text { calon siswa baru. }\end{array}$ \\
\hline
\end{tabular}




\begin{tabular}{|c|c|c|c|}
\hline 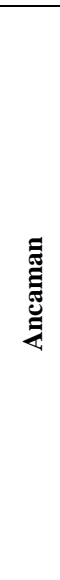 & $\begin{array}{l}\text { - Persaingan dari sekolah lain } \\
\text { baik swasta maupun negeri } \\
\text { yang memiliki program } \\
\text { keahlian yang sama } \\
\text { - Munculnya sekolah negi yang } \\
\text { biayanya gratis seperti Sekolah } \\
\text { Menengah Atas (SMAN) } \\
\text { - Permintaan lulusan yang } \\
\text { berkualitas tinggi baik dari } \\
\text { pemerintah maupun DU/DI } \\
\text { - Persaingan antar lulusan dalam } \\
\text { merebut peluang kerja sangat } \\
\text { tinggi } \\
\text { - Perkembangan teknologi yang } \\
\text { semakin cepat kebijakan } \\
\text { - Regulasi dan pelalu } \\
\text { pemerintah yang selah } \\
\text { berubah a }\end{array}$ & $\begin{array}{l}\text { Strategi Pemanfaatan } \\
\text { Kekuatan dalam } \\
\text { Mengatasi Ancaman } \\
\text { - Meningkatkan mutu } \\
\text { sekolah dan kualitasn } \\
\text { lulusan } \\
\text { - Selalu mengikyti } \\
\text { perkembangan } \\
\text { teknologi } \\
\text { - Meningkatkan } \\
\text { kualita kurikulum } \\
\text { (terutama kurikulum } \\
\text { program produktif) } \\
\text { untuk selalu update } \\
\text { sesuai dengan } \\
\text { kebutuhan DU/DI }\end{array}$ & $\begin{array}{l}\text { Strategi Mengatasi Kelemahan dan Ancaman } \\
\text { - Meningkatkan kualitas SDM dengan cara } \\
\text { memberi peluang kepada semua guru untuk } \\
\text { melakukan pelatihan } \\
\text { - Meningkatkan antisipasi dengan } \\
\text { mensosialisasikan kepada staf dan guru terhadap } \\
\text { kebijakan pemerintah } \\
\text { - Mengadakan studi banding ke perusahaan untuk } \\
\text { update teknologi yang digunakan perusahaan }\end{array}$ \\
\hline
\end{tabular}

b. Analisis Faktor Penentu Keperhasilan (Critical Success Factor (CFS))

Analisis CSF merupakan sebuah metode yang kuat untuk mengkonsentrasikan kunci kebutuhan yang diperlukan oleh sebuah organisasi. Untuk menganalisis CSF ini, dapat dilihat dari misi organisasi yaitu misi dari SMK Yamatu Tualang yang menghasilkan tujuan strategi yang dapat diwujudkan sebagai dasar pelaksanaan dari setiap nilai misi yang dibuat oleh pihak SMK Yamatu Tualang.

Tabel 3 Analisis CFS

\begin{tabular}{|c|c|c|}
\hline Misi SMK Yamatu Tualang & Faktor Penentu Keberhasilan & Tujuan Strategis \\
\hline $\begin{array}{l}\text { Memberikan Pelayanan kepada peserta } \\
\text { diklat dan masyarakat DU/DI dengan } \\
\text { pelayanan yang maksimal. }\end{array}$ & $\begin{array}{l}\text { Memaksimalkan kerja sama dengan } \\
\text { perusahaan atau instansi dalam hal } \\
\text { membentuk keahlian peserta didik. }\end{array}$ & $\begin{array}{l}\text { Melahirkan peserta didik yang } \\
\text { kompeten dalam menguasai } \\
\text { bidang keahliannya. }\end{array}$ \\
\hline $\begin{array}{l}\text { Mengutamakan kualitas dan disiplin yang } \\
\text { tinggi, baik dalam kegiatan belajar } \\
\text { mengajar maupun kegian ekstra kulikuler. }\end{array}$ & $\begin{array}{l}\text { Menerapkan aturan yang berlaku baik } \\
\text { peserta didik maupun tenaga pendidik } \\
\text { yang menyiapkan sumber daya manusia } \\
\text { serta sarana dan prasarana. }\end{array}$ & $\begin{array}{l}\text { Melahirkan peserta didik yang } \\
\text { disiplin dan mampu } \\
\text { menguasai bidang keahlian } \\
\text { yang diminatinya. }\end{array}$ \\
\hline $\begin{array}{l}\text { Meningkatkan kualitas } \\
\text { produktif, normatif maı }\end{array}$ & $\begin{array}{l}\text { Membangun teknologi informasi atau } \\
\text { sistem informasi untuk memudahkan } \\
\text { aktivitas pendidikan }\end{array}$ & $\begin{array}{l}\text { Memiliki sumber daya yang } \\
\text { berkualitas baik. }\end{array}$ \\
\hline $\begin{array}{l}\text { Meningkatkan peran serta dunia usaha dan } \\
\text { masyarakat dalam dunia pendidikan. }\end{array}$ & $\begin{array}{l}\text { Meningkatkan kerjasama dengan } \\
\text { perusahaan atau instansi yang berkaitan. }\end{array}$ & $\begin{array}{l}\text { Kelancaran pada saar praktek } \\
\text { kerja industri. }\end{array}$ \\
\hline $\begin{array}{l}\text { Menanamkan kepada peserta diklat norma- } \\
\text { norma agama serta menciptakan } \\
\text { lingkungan yang berbudaya melayu. }\end{array}$ & 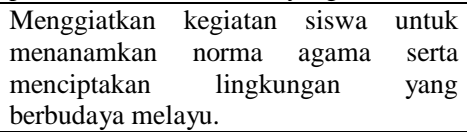 & $\begin{array}{l}\text { Kelancaran penerapan norma- } \\
\text { norma agama serta } \\
\text { lingkungan yang berbudaya } \\
\text { melayu. }\end{array}$ \\
\hline
\end{tabular}

\subsection{Analisis Lingkungan Bisnis Eksternal Organisasi}

a. Porter Lima Ancaman

Analisa ancaman dan peluang pada SMK Yamatu Tualang dilakukan untuk melihat posisi dan persaingan lingkungan eksternal. Analisa dilakukan menggunakan analisis Lima Ancaman Porter (Porter Five Forces), adapun hasil dari analisis Lima Ancaman Porter disajikan pada Tabel 4.

Tabel 4 Hasil Analisis Porter Lima Ancaman

\begin{tabular}{|c|c|c|}
\hline Lima Ancaman Porter & Objek Ancaman & $\begin{array}{l}\text { Pengaruh Terhadap } \\
\text { SMK Yamatu Tualang }\end{array}$ \\
\hline 1. Pesaing yang sudah ada & $\begin{array}{l}\text { Adanya sekolah yang memiliki } \\
\text { program keahlian yang sama, yaitu } \\
\text { SMKS YPPI Tualang }\end{array}$ & Tinggi \\
\hline 2. $\quad$ Kekuatan menawar pemasok & $\begin{array}{l}\text { Sekolah menengah tempat calon } \\
\text { siswa mendaftar berasal dari SMP dan } \\
\text { MTs yang ada di Kecamatan Tualang } \\
\text { ataupun yang di luar Kecamatan } \\
\text { Tualang. }\end{array}$ & Rendah \\
\hline $\begin{array}{l}\text { 3. Kekuatan Menawar pelanggan- } \\
\text { pelanggan }\end{array}$ & $\begin{array}{l}\text { Kekuatan yang ditawarkan dari sisea } \\
\text { SMK Yamatu Tualang kepada } \\
\text { masyarakat terhadapa keunggulan } \\
\text { SMK Yamatu Tualang yaitu sudah } \\
\text { terakreditasi. }\end{array}$ & Rendah \\
\hline 4. Ancaman-ancaman pesaing baru & $\begin{array}{l}\text { Ancaman lahirnya sekolah-sekolah } \\
\text { baru lainnya yang berada dari } \\
\text { program keahlian yang ditawarkan } \\
\text { SMK Yamatu tualang seperti SMKN } \\
\text { 1 Tualang serta banyaknya SMAN }\end{array}$ & Tinggi \\
\hline
\end{tabular}




\begin{tabular}{|c|c|c|}
\hline Lima Ancaman Porter & Objek Ancaman & $\begin{array}{c}\text { Pengaruh Terhadap } \\
\text { SMK Yamatu Tualang }\end{array}$ \\
\hline & $\begin{array}{l}\text { baru yang bermunculan dengan biaya } \\
\text { gratis. }\end{array}$ & \\
\hline $\begin{array}{ll}\text { 5. } & \text { Ancaman produk-produk atau } \\
\text { jasa pengganti }\end{array}$ & $\begin{array}{l}\text { Keberadaan lembaga-lembaga kursus } \\
\text { komputer seperti Shopia Com } \\
\text { sehingga tidak menambah inputan } \\
\text { siswa. }\end{array}$ & Tinggi \\
\hline
\end{tabular}

\subsection{Analisis Lingkungan Internal SI/TI}

Perangkat lunak yang digunakan di SMK Yamatu Tualang dapat dilihat pada Tabel 5 dengan menggunakan tabel analisis Mc Farlan Strategy Grid. Mc Farlan Strategy Grid digunakan untuk memetakan aplikasi SI berdasarkan kontribusinya terhadap organisasi. Beberapa aplikasi yang digunakan pihak SMK Yamatu Tualang diatas, rincian aplikasi-aplikasi tersebut dipetakan ke dalam sebuah tabel analisis Mc Farlan Starategy Grid, posisi aplikasi tersebut dapat dilihat sebagai berikut:

\begin{tabular}{|c|c|}
\hline \multicolumn{2}{|c|}{ Tabel 5 Portofolio Perangkat Lunak } \\
\hline Strategic & High Potential \\
\hline E-Mail & Web Browser \\
\hline Microsoft Office & Adobe Photoshop \\
\hline Key Operational & Support \\
\hline
\end{tabular}

\subsection{Analisis Lingkungan Eksternal SI/TI}

Teknologi informasi pada pendidikan adalah didasarkan pada pemanfaatannya dalam bidang pendidikan. Dalam bidang pendidikan, pemanfaatan teknologi informasi difokuskan pada peningkatan kualitas pembelajaran sehingga dapat meningkatkan kualitas pendidikan. Adapun definisi teknologi informasi pendidikan adalah ilmu pengetahuan dalam bidang informasi berbasis komputer yang digunakan dalam peningkatan kualitas pendidikan [6]. Tabel 6 merupakan tabel analisis lingkungan eksternal SI/TI pada SMK Yamatu Tualang.

Tabel 6 Analisis Lingkungan Eksternal SI/TI

\begin{tabular}{|c|c|c|}
\hline Tren Teknologi & Ketersediaan & Keterangan \\
\hline 1. Jaringan Komputer: & & \\
\hline a. Jaringan WAN & $\mathrm{X}$ & Belum diimplementasikan \\
\hline b. Jaringan MAN & $\mathrm{X}$ & Belum diimplementasikan \\
\hline c. Jaringan LAN & $\sqrt{ }$ & Belum optimal \\
\hline d. Wifi & $\sqrt{ }$ & Belum optimal \\
\hline 2. $\quad$ Electronic Mail & $\sqrt{ }$ & Belum optimal \\
\hline 3. Mailing List & $\mathrm{X}$ & Belum diimplementasikan \\
\hline 4. Video-conference & $\sqrt{ }$ & Belum optimal \\
\hline 5. Portal Organisasi & $\mathrm{X}$ & Belum diimplementasikan \\
\hline e-Learning & $\mathrm{X}$ & Belum diimplementasikan \\
\hline 7. Webservice & $\mathrm{X}$ & Belum diimplementasikan \\
\hline $\begin{array}{lll}\text { 8. } & \text { Computer Based Information } \\
\text { System (CBIS) }\end{array}$ & $\mathrm{X}$ & Belum diimplementasikan \\
\hline 9. SMS Gateway & $\mathrm{X}$ & Belum diimplementasikan \\
\hline
\end{tabular}

\subsection{Perencanaan Strategi}

\section{A. Strategi Bisnis Sistem Informasi}

Perumusan strategi bisnis sistem informasi mencakup tentang bagaimana setiap unit/fungsi bisnis akan memanfaatkan SI/TI untuk mencapai sasaran bisnisnya. Strategi bisnis sistem informasi pada SMK Yamatu Tualang dapat dilihat pada Tabel 7.

Tabel 7 Strategi Bisnis Sistem Informasi

\begin{tabular}{|l|l|l|}
\hline \multirow{3}{*}{1.} & Website Resmi SMK Yamatu Tualang \\
\cline { 2 - 3 } & Deskripsi & $\begin{array}{l}\text { Merupakan alikasi berbasis web yang menampilkan informasi-informasi } \\
\text { penting tentang profil sekolah, program dan kegiatan sekolah, data pendidik, } \\
\text { peserta didik, dan kegiatan sekolah lainnya. }\end{array}$ \\
\cline { 2 - 3 } & Tujuan & $\begin{array}{l}\text { Sebagai sarana media informasi dan sosialisasi dan komunikasi online serta } \\
\text { sarana untuk meningkatkan kualitas layanan sekolah kepada pemerintah dan } \\
\text { masyarakat luas. }\end{array}$ \\
\cline { 2 - 3 } 2. & Penggunaan & Administrator dan masyarakat luas. \\
\cline { 2 - 3 } & Portal Alumni dan Karir & \multicolumn{2}{|l|}{$\begin{array}{l}\text { Merupakan aplikasi berbasis web yang digunakan untuk menyimpan dan } \\
\text { menampilkan daftar alumni serta menjembatani antara perusahaan ataupun } \\
\text { DU/DI yang sedang membutuhkan tenaga kerja dengan para alumni yang } \\
\text { sedang membutuhkan pekerjaan. }\end{array}$} \\
\hline
\end{tabular}




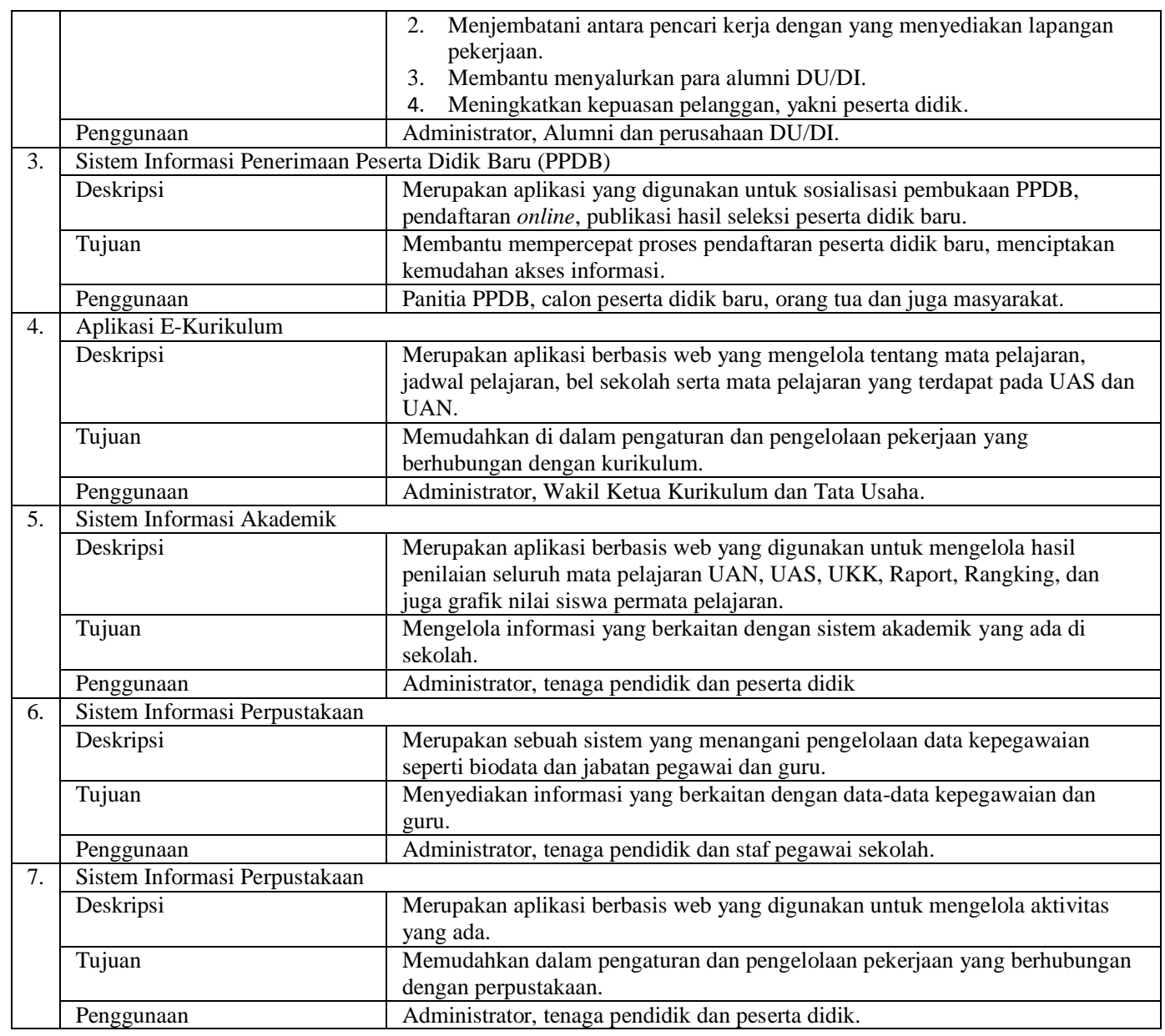

B. Strategi Manajemen SI/TI

Perencanaan strategi SI/TI yang diusulkan tentunya akan berjalan baik apabila didukung dengan perencanaan strategi manajemen SI/TI yang sesuai dengan solusi SI/TI yang telah dibuat. Penerapan usulan SI/TI yang baru nantinya, hendaklah didukung oleh SDM TI yang berkompeten dibidangnya seperti yang disajikan pada Tabel 8.

Tabel 8 Kebutuhan SDM TI SMK Yamatu Tualang

\begin{tabular}{|l|l|l|l|}
\hline \multicolumn{1}{|c|}{ Pendefinisian Kebutuhan } & \multicolumn{1}{c|}{ Posisi } & \multicolumn{1}{c|}{ Pendidikan } & \multicolumn{1}{c|}{ Jumlah } \\
\hline Staff Development & Web Developer & S1/D3 Ilmu Komputer & 1 orang \\
\hline Staff Maintenance & Network Administrator & S1/D3 Ilmu Komputer & 1 orang \\
\hline Staff Support & Technical Support & S1/D3 Ilmu Komputer & 1 orang \\
\hline
\end{tabular}

\section{Strategi TI}

Strategi TI merupakan pemetaan dari solusi kebutuhan infrastruktur TI yang digunakan untuk mendukung terwujudnya solusi SI seperti yang telah dijelaskan pada strategi bisnis SI. Berdasarkan analisis internal dan eksternal kondisi SI/TI pada SMK Yamatu Tualang maka Tabel 9 merupakan hasil perumusan strategi teknologi informasi.

Tabel 9 Strategi Teknologi Informasi

\begin{tabular}{|c|c|c|c|}
\hline No & Permasalahan & Solusi Teknologi & Manfaat \\
\hline 1 & $\begin{array}{l}\text { Penggunaan jaringan internet belum optimal } \\
\text { kerena jumlah bandwith tidak mampu } \\
\text { mengakomodir jumlah seluruh user yang ada } \\
\text { dan hanya dapat diakses oleh pagawai untuk } \\
\text { kepentingan pribadi. }\end{array}$ & Jaringan LAN & $\begin{array}{l}\text { Peran LAN dapat dilihat dalam } \\
\text { penyediaan informasi yang dapat } \\
\text { diperoleh dengan cepat untuk } \\
\text { pembelajaran, kegiatan akademik dan } \\
\text { kegiatan administrasi sekolah. }\end{array}$ \\
\hline 2 & $\begin{array}{l}\text { Pendaftaran bagi calon siswa baru masih } \\
\text { manual, belum memiliki sistem sendiri untuk } \\
\text { menyimpan data siswa. }\end{array}$ & $\begin{array}{l}\text { Web service } \\
\text { informasi }\end{array}$ & $\begin{array}{l}\text { Memudahkan atau mendukung } \\
\text { pengelolaan dan distribusi informasi } \\
\text { layanan/ hasil jasa kependidikan dari } \\
\text { pihak SMK Yamatu Tualang dengan } \\
\text { siswa. }\end{array}$ \\
\hline 3 & $\begin{array}{l}\text { Tidak tersedianya sarana untuk penerapan } \\
\text { teknologi informasi dan komunikasi, } \\
\text { pengelolaan perpustakaan masih manual, } \\
\text { ketersedian buku perpustakan yang belum } \\
\text { memenuhi kebutuhan, peralatan praktek }\end{array}$ & $\begin{array}{lr}\text { Sistem } & \text { Informasi } \\
\text { Berbasis Komputer } \\
\text { (sistem informasi } \\
\text { perpustakaan dan } \\
\text { aplikasi } & \text { - } \\
\text { Kurikulum) }\end{array}$ & $\begin{array}{l}\text { Memilhara data, integrasi data secara } \\
\text { menyeluruh, memudahkan dalam } \\
\text { membuat ringkasan data serta } \\
\text { menampilkan informasi yang dapat } \\
\text { dijadikan bahan pemecahan masalah }\end{array}$ \\
\hline
\end{tabular}




\begin{tabular}{|c|l|l|l|}
\hline No & \multicolumn{1}{|c|}{ Permasalahan } & Solusi Teknologi & \multicolumn{1}{c|}{ Manfaat } \\
\hline & $\begin{array}{l}\text { peserta didik yang masih kurang serta sekolah } \\
\text { kekurangan tenaga pendidik produktif. }\end{array}$ & & $\begin{array}{l}\text { yang ada diberbagai organisasi dengan } \\
\text { lebih cepat dan tepat. }\end{array}$ \\
\hline 4 & $\begin{array}{l}\text { Belum ada media promosi ke masyarakat luas } \\
\text { sebagai tindakan mengatasi persaingan } \\
\text { dengan sekolah lainnya. }\end{array}$ & $\begin{array}{l}\text { Portal organisasi } \\
\text { (Website } \\
\text { sekolah) }\end{array}$ & $\begin{array}{l}\text { Sebagai media promosi bagi SMK } \\
\text { Yamatu Tualang kepada masyarakat } \\
\text { luas agar mengetahui potensi dan } \\
\text { keunggulan SMK Yamatu Tualang. }\end{array}$ \\
\hline
\end{tabular}

\subsection{Portofolio Aplikasi}

Hasil akhir dari perencanaan strategi sitem dan teknologi informasi ini adalah terbentuknya portofolio aplikasi yang memberikan hasil sistem dan teknologi informasi yang dibutuhkan oleh SMK Yamatu Tualang.

Tabel 10 Portofolio Aplikasi

\begin{tabular}{|l|l|}
\hline \multicolumn{1}{|c|}{ Strategic } & \multicolumn{1}{c|}{ High Potential } \\
\hline Website Resmi Sekolah & $\begin{array}{l}\text { Sistem Informasi PPDB } \text { online } \\
\text { Sistem informasi Alumni dan Karir }\end{array}$ \\
\hline $\begin{array}{l}\text { Sistem Informasi Akademik } \\
\text { Aplikasi } \text {-Kurikulum } \\
\text { Sistem Informasi Kepegawaian }\end{array}$ & Sistem Informasi Perpustakaan \\
\hline \multicolumn{1}{|c|}{ Key Operational } & \multicolumn{1}{c|}{ Support } \\
\hline
\end{tabular}

\section{Kesimpulan}

Portofolio aplikasi perencanaan strategi sistem dan teknologi informasi mendatang sebagai perencanaan kedepan pada SMK Yamatu Tualang adalah:

1. Website resmi sekolah terletak pada level Strategic.

2. Sistem informasi akademik, sistem informasi kepegawaian dan aplikasi E-kurikulum terletak pada level Key Operational.

3. Sistem informasi PPDB online serta Sistem Informasi Alumni dan Karir terletak pada level High Potential.

4. Sistem informasi perpustakaan terletak pada level Support.

\section{Daftar Pustaka}

[1] Darmizal, Teddie, dkk. "Perencanaan Strategi Sistem Informasi dan Teknologi Informasi". Penerbit Fakultas Sains dan Teknologi UIN Suska Riau, Pekanbaru. 2015.

[2] Jogiyanto, HM. “Sistem Teknologi Informasi”. Penerbit Andi, Yogyakarta. 2005.

[3] Jogiyanto, HM. “ Sistem Informasi Strategik”. Penerbit Andi, Yogyakarta. 2010.

[4] Jogiyanto, HM. “ Sistem Teknologi Informasi Bisnis Pendekatan Strategi”. Penerbit Salemba Empat, Jakarta. 2013.

[5] Kristanto, Andri." Perancangan Sistem Informasi dan Aplikasinya”. Penerbit Gava Media, Yogyakarta. 2003.

[6] Prasojo dan Riyanto. "Teknologi Informasi Pendidikan”. Penerbit Gava Media, Yokyakarta. 2010.

[7] Rangkuti, Freddy."Analisis SWOT Teknik Membedah Kasus Bisnis". Penerbit PT Gramedia Pustaka Utama, Jakarta. 2008.

[8] Wahyono, Teguh.2004."Sistem Informasi (konsep dasar, analisis desain dan implementasi)". Penerbit Graha Ilmu, Yogyakarta. 2004.

[9] Wedhasmara, Ari. "Langkah-langkah Perencanaan Strategi Sistem Informasi dengan Menggunakan Metode Ward and Peppard". Jurnal Sistem Informasi Vol. 1 No.1, April 2009. 